\title{
Social Dance (shakō dansu) in Japan: Between Sociability and Sport
}

\author{
Kristina Veemees
}

\begin{abstract}
Since the film Shall We Dansu? (1996) and many TV shows, social dance has become known to a wider audience in Japan. Nevertheless, prejudices such as 'That doesn't suit the Japanese' continue to exist, because the intimate body contact in ballroom dancing is hard to accept in a culture where 'skinship' (body contact) is only important during childhood. For this reason, dance schools were under the law controlling Japanese entertainment and the sex industry until 1998. This article deals with the historical situation and cultural issues of social dance in Japan.
\end{abstract}

Keywords: social dance, ballroom dance, Japan, sociability, body contact Sport." In Vienna Graduate Journal of East Asian Studies, Volume 1, eds. Rudiger Frank, Ingrid Getreuer-Kargl, Lukas Pokorny and Agnes Schick-Chen. Vienna: Praesens Verlag, 2011, pp. 123-145. https://doi.org/10.2478/vjeas-2011-0005 


\section{Introduction}

\section{Aims of the research on social dance in Japan}

In the 1970s and 1980s, it was proclaimed that social dance in Japan would die out very soon, because elderly people were the only ones interested in this culture. These prospects proved to be wrong. Although social dance is performed only by a small number of people nowadays, ${ }^{1}$ the participants are very active.

What is the major problem for starting dance lessons? It is the fear of an unknown world. Even at public schools, dance lessons were uncommon till the 1990s. There are two reasons why plans for adopting dance lessons in schools failed to happen. Firstly, dance schools for many years came under the füzoku eigyōhō 風俗 営業法, the law controlling the Japanese entertainment and restaurant industry, which reinforced the immoral image of the shako dansu 社交ダンス and kept underage young people from entering dance schools. Social dance, which should be a means of enhancing sociability (shakōsei 社交性), was labelled as 'sports'.

Secondly, the intimate body contact of social dance figures finds no basis in Japanese culture. There is just no habit of 'skinship' (body contact スキンシップ), which is important only during childhood. In adult life, body contact is very restricted, and this cultural pattern leads to a feeling of shame when performing social dances that are judged indecent and to shyness, which prevents many Japanese from starting shako dansu.

This article, based on my graduation thesis, ${ }^{2}$ deals with social dance as a cultural phenomenon in Japan, analyses the connections between non-verbal communication, 'skinship' (which is explained below in the section on 'Non-verbal communication and 'skinship'), and the feeling of embarrassment and shame, and introduces the prevailing social attitude towards this unknown culture (ibunka 異文化).

Social dance has never been a target of research in Japanese studies. Some authors like Mehl (2005) or Taylor Atkins (2001) have mentioned social dance in their papers; Savigliano (1992) wrote about dance, but concentrated mainly on tango. The Japanese film Shall we dansu? (Shall we ダンス, 1996) has been reviewed in some articles, ${ }^{3}$ but the history of social dance in Japan has been treated only superficially.

The Japanese discourse about social dance started in the 1920s and 1930s, at first dealing with steps and figures and the architecture of dance halls. Nakagawa was the first to write a history of social dance in Japan (1977), Nagai followed in 1991. Apart from books on the technique of ballroom dancing, only dance critic Kawakita

1 The number of Japanese who regularly perform social dance is estimated at 10 million, about 7.8 percent of the population (Kaneko 2003:48).

2 Veemees 2006a, an abstract published as 2006b.

3 For example Goldstein-Gidoni and Daliot-Bul (2002). 
$(1995,2002)$ was keen to focus his attention on elderly society and the possibilities of communication through social dance.

\section{What is social dance?}

Before getting to know the history of social dance in Japan, let me introduce several terms used for expressing social dance and its functions. In general, talking about social dance means talking about dances where sociability and socialising are the primary focuses of dancing, including folk dances or religious dances. To make a clear distinction between this broad variety of dances, European-American dances like waltz, tango, rumba, etc. are called ballroom dances.

At the beginning of the Meiji era, ballroom dancing was called 'social dance' (soshiaru dansu ソシアルダンス) in Japan, a term which was soon replaced by the Japanese translation shakō dansu. Shakō means sociability and clearly expresses the character of these dances ${ }^{4}$ (Nakagawa 1977: 220). When talking about soshiaru dansu in Japan now, the meaning is slightly different, because it emphasises that a couple (married couple or lovers) is dancing together (Kawakita 1995: 11). Dance critic Kawakita also uses the hardly known term zeneraru dansu ゼネラルダンス (general dance), social dance for amateurs with easy step combinations (Kawakita 1995: 96).

Dance sport finds its expression not only in the terms $k y \overline{o g i}$ dansu 競技ダンス (competitive dance) or dansu supōtsu ダンススポーツ (dance sport) but also in bōrurūmu dansu ボールルームダンス (ballroom dancing). As one can see, what is called 'ballroom dancing' in the English language nowadays has a different meaning in Japan. There, 'ballroom dance' is only used for competitive dance sport.

\section{A brief history of social dance in Japan}

\section{From Meiji to World War II}

Whereas the European history of social dance had already started during the 15 th and 16th centuries, it is still a young culture in Japan. After the opening of the country (kaikoku 開国) to the Western world, Japanese politicians and philosophers were confronted with new developments in technology and economy. The first occasion on which Japanese people happened to see social dance can be set in the year 1860, when a Japanese delegation visited America and was invited to a

4 For this reason I use the English term 'social dance' in this article to express the difference between competitive dance and socialising dance. 
banquet. Muragaki Norimasa 村垣範正 wrote about this experience in his diary (Kōkai nikki 航海日記), stating how he and other delegates were stunned that there was no elegance in this dance between couples, but that everybody in America seemed to love it (Nagai 1991: 16). Fukuzawa Yukichi had similar experiences and noted that he and his colleagues were about to laugh out loudly when watching couples jumping about the hall (Fukuzawa 1971: 135). Shibusawa Eiichi too was astonished, but, being positive towards foreign culture, he realised that social dance would be necessary for social intercourse with foreigners in Japan.

The reason why the Japanese were bewildered when seeing social dance for the first time was simply because the upper social classes were not familiar with this new presentation of women. Whereas in Japan, male and female society could be considered as strictly separated, in America women enjoyed life at the side of men, who followed the rules of 'ladies first'. In Edo Japan the maxim was 'otoko wa soto, onna wa uchi'男は外、女は内 (men are outside, women inside), and at the beginning of the Meiji era the writings of the Confucian moralist Kaibara Ekken 貝原益 軒 (1613-1740) on women's behaviour became popular. As prescribed by his doctrine, girls and boys should be separated from early childhood and avoid physical contact (Neuss-Kaneko 1990: 26).

But as the idea of bunmei kaika 文明開化, the Westernisation movement, spread through the country at the beginning of the Meiji era, not only Western-style clothes, food and habits were introduced but also social dance. Documents show that dinners and banquets for ambassadors, politicians and foreigners were already being held in 1862 and on such occasions social dance was first seen and danced in Japan (Nagai 1991: 20). Japanese women of the upper classes now had to represent the new Japan together with their husbands at balls instead of being at home.

For such occasions a hall was soon needed and the British architect Josiah Conder constructed the Rokumeikan 鹿鳴館 (Hall of the roaring deer), which opened on 28 November 1883. Its architecture had a strong resemblance to an Italian palace in Renaissance style. The ground floor was dedicated to a dance hall, while on the first floor a restaurant, a hotel, a library and a billiard room awaited the guests. This building gave that epoch a new name: Rokumeikan era (Kuno 1993: 153-154).

At the beginning only foreigners or experienced Japanese danced, but soon the German dancing teacher, Johannes Ludwig Janson, was invited and taught the waltz, polka and quadrille (Mehl 2005: 163). In 1884, the Rokumeikan balls were critically reviewed in newspapers for the first time. Social dance with its intimate embracing would provoke vulgarity and therefore cause moral damage. Some scandals at banquets ${ }^{5}$ were reported in the press and soon the Rokumeikan era ended. Social dance

5 For example, politician Itō Hirobumi had an affair with a married woman from high society during a masquerade ball in 1887 (Mehl 2005: 168, 176; Seidensticker 1983: 100). 
was removed from public life, although dance parties were held at the newly built Imperial Hotel (teikoku hoteru 帝国ホテル) (Takeuchi 1997: 21-26).

At the beginning of the Taishō era, the Ōsaka Mainichi Shimbun 大阪毎日新聞 reported the 'dance problem' (1907), when female teachers from local high schools taught business men social dance at the Ōsaka Hotel (Nagai 1991: 31-32). After this scandal social dance was avoided by Japanese until the middle of the Taishō era. In 1920, the Kagetsuen 花月園 amusement park in Tsurumi (Yokohama) opened to the public. The director's wife had travelled abroad before and insisted on preparing a dance hall for ladies and gentleman at the place. Since entry tickets were very expensive, these facilities were used only by wealthy Japanese and foreign people (Nakagawa 1977: 45-46, Kawakita 2002: 18).

During World War I, the foxtrot and jazz music were introduced to Japan, and a new style of living in big cities like Tōkyō, Yokohama, Ōsaka, Kyōto and Kōbe emerged in the 1920s. The Russian ballerina Eliana Pavlova, who emigrated during the war, began teaching social dance and manners in Tōkyō. Cafés and cinemas as well as dance halls reflected this period of internationalisation (Taylor Atkins 2001: 54).

At the same time the role of women started to change, and the moga モガ (modern girls ${ }^{6}$ ) strolling through the cities used social dance as a means for informal gatherings with men. This new female type was portrayed by Tanizaki Junichirō in Chijin no ai 痴人の愛(1924-25), a novel depicting customs in Tōkyō at the end of the Taishō era. Using the voice of his leading character, modern girl Naomi, Tanizaki tells that social dance still has negative connotations: "just because of holding hands when dancing, everybody assumes prohibited relationships and talks gossip'7 (Tanizaki 2005: 198).

Although many modern girls loved the fashionable social dance, others could not work up any enthusiasm for it. Author Miyake Tsuyako wrote that she '[...] went three days to dance lessons, but then it started to be boring, because there were no gentlemen wearing elegant tuxedos as she has seen in the movies' (Miyake 1981: 47).

But as a matter of fact, the modern woman also participated in business (shokugyo fujin 職業婦人), and as a forerunner of the hostess, the working sector of joky $\bar{u}$ (waitress 女給), who takes care of male clients in bars and cafés, emerged. After the Great Kantō Earthquake, Ōsaka and Kōbe became centres of social dance and the dance club Cottage started with a ticket system where male clients could buy a ticket for a dance with a female taxi dancer ('One dance, one ticket'). Based on an Ameri-

6 The construction of the concept of modern girls has been discussed by Bollinger (1994).

7 All translations from the Japanese by Kristina Veemees. 
can model, ${ }^{8}$ this new business turned out to be very successful, but was criticised by moralists and newspapers (Nagai 1991: 62). But in fact these taxi dancers ${ }^{9}$ were women from the lower classes who needed the money for the necessities of life. Kometa Sadako 米田貞子, a taxi dancer, complained in the magazine Nyonin geijutsu 女人芸術 (1928) that many people considered her to be dubious, although she was working hard and seriously like 'a mechanical puppet'. Unfortunately she had to admit that some of her colleagues also kept up sexual relationships with wealthy business men (Nakashima 1975: 149-150).

In 1926 the dance fever in Ōsaka had reached its peak. When the Tennō died in December the government ordered that dance halls, cafés and cinemas close for six days for mourning ceremonies. But dance halls in Ōsaka re-opened immediately after the six days, which made the municipal office think of other restraints: from 1927 every guest had to write down their name and address at the reception desk of dance halls. Sitting with taxi dancers, dates and alcohol outside the hall were forbidden (Taylor 2001: 63). After a trading ban imposed by the Ōsaka municipal government, all dance halls had to close down on 26 December 1927. Taxi dancers lost their occupations, moved east, and Tōkyō again became the centre of social dance.

Although supervision by the police was strict in Tōkyō too, the success of these amusement places could not be diminished. The Florida dance hall was the most famous hall in Tōkyō, even Hollywood stars like Charlie Chaplin visited the place (Taylor 2001: 73). But despite this popularity, dance halls and even dance studios of the Japanese Association of Teachers of Dancing (JATD), which was founded in 1931, came under the control of the police. ${ }^{10}$ A glance at the historical background might show the reasons for this development: from 1931 Japan was in conflict with China, and increasing nationalism led to social dance being criticised as beiei kyōrakushugi 米英享楽主義 (American-British hedonism) (Segawa 2005: 362). From 1938, women, students and underage people were not admitted to dance halls and guests had to register when entering a hall. But at the same time the war with China started and the demand for amusement decreased rapidly. The government propagated the slogan 'luxury is our enemy' (zeitaku wa teki da 贅沢は敵だ), and on 1 November 1940 all dance halls in Japan had to close (Segawa 2005: 364).

To summarise the development of social dance in pre-war Japan, it is evident that social dance was limited to dance halls and because of the taxi dancer systems only

8 Since World War I taxi dancers were a kind of distraction for unmarried American sailors on holiday (Segawa 2005: 122).

9 Taxi dancer: Like a taxi driver female dancers were considered to be a public service. For some citations of Japanese taxi dancers see Takahashi 2004a: 451, 457, 463 and Nagai 1991: 101.

10 Some scandals (so-called momoiro-jiken 桃色事件, pink scandals) contributed to the bad image of social dance, e.g. a male dance teacher had unserious relationships with the married wives of managers, etc. (Nagai 1991: 119-122; Segawa 2005: 362). 
an amusement facility for men at sakariba 盛り場. ${ }^{11}$ The aspect of social dance as a business shows that communication between the sexes in public was still restricted at that time.

\section{After World War II}

Tōkyō was destroyed during the war, but was soon rebuilt. The American army loved jitterbug and went to the newly opened dance hall, Oasis of Ginza, which was located in the Matsuzakaya department store in Ginza. A poster at the front door said 'Japanese off limits', but as dancing partners Japanese women (and geisha 芸者 too), who had lost their families in the war and had to earn their own money, were hired (Makino 2003: 37-42; Kawakita 2002: 156). After the establishment of the Recreation and Amusement Association (RAA), social dance was not prohibited any more, but those few dance bars existing in Tōkyō were not used by the Japanese.

In the 1950s, young Japanese people discovered social dance as a means of sociability and communication between the sexes. Even in rural regions where no dance clubs existed, they went to public spaces and spent time dancing tango, blues or circle dances in front of temples or shrines. At workplaces in cities, shokuba dansu 職場ダンス (workplace dance) brought relief from stress through dancing during the lunchtime break or after work (Nakagawa 1977: 150-158).

After the war it became usual to consume alcohol at dance halls, which made it difficult to draw a line between dance halls and commercial cabarets. These two amusement facilities co-existed after the war, in fact dance halls were used as dance studios during the daytime and as cabarets in the evening, and so changed the teachers into hostesses (Nagai 1991: 194).

The mambo became popular in 1955 and replaced social dances with body contact like the waltz. Dances almost without body contact seemed to be adapted to Japanese life much faster than intimate dances. Despite this, social dance lost its popularity in the 1970s, when disco life became dominant. Only elderly people started dancing again, remembering their youth. The Japan Broadcasting Company (NHK) broadcast the programme Let's Dance! in 1985, and a second dance boom, which is connected with the füzoku eigyōho (law concerning the amusement/sex industry) began. The füzoku eigyōhō was revised twice after its passing in 1948 (1984-85 and 1998-99). In fact, restaurants, cafés and teahouses as well as dancing schools were governed by it until 1984. Underage people were not allowed to enter a dance school. In 1984 the law was changed, so that persons under 20 years could learn social dances too, but to maintain public morals only qualified dancing teachers were allowed to give instruction. The training of dancing teachers-to-be was 
supervised by the All Nippon Association of Dance (ANAD) and the Japanese Ballroom Dance Federation (JBDF), yet was finally controlled by the committee for public security. Since 1998 dance schools have not come under the füzoku eigyōhō any more (CIO Renraku Kaigi 2004).

Social dance has always played a big role in European and American education for young people. In dance schools, not only dance choreographies but also manners are a target. Already in the European Renaissance, dance provided not only physical but also intellectual education (Brainard 2001: 60). This concept never existed in Japan, and as a result of its connection with the füzoku eigyōhō, social dance has been emphasised as a sport. Originally a vehicle of sociability, social dance in Japan is called a sport which has to be mastered through competition. Of course there exist many dance circles (dansu sakuru ダンスサークル) for the elderly, which have been functioning since the 1990s, but this aspect is not presented in the media. Broadcasting companies stress social dance as an artificial dance which needs a (mostly female) audience (like figure skating), and in TV programmes such as Urinari geinōjin shakō dansu-bu ウリナリ芸能人社交ダンス部 (NTV 2006) or Dansu wa ichiban ダンスは一番, prominent performers try to dance like professionals and win against other competitors. Prejudice and the mass media led to social dance becoming an art. When I went to a dance competition for amateurs (27 November 2005), apart from family members there were no other spectators. By contrast, at the professional competitions of the Tōkyō Dance Championships (4 December 2005) the situation had changed to become an event like a soccer match, where fans (mostly women) were waving flags and shouting the favourite couple's name. As in the world of figure skating, fans seemed to know everything about the young professional dancers.

In the film Shall We Dansu? (Suō Masayuki 1996a and the American remake 2005) too, the leading part starts training early on for a competition. To get an insight into social dance clubs I participated at a dance circle at the Kawasaki International Centre ${ }^{12}$ in August 2006. Two teachers belonging to the Nippon Dance Sport Federation (JDSF) welcomed me and my partner and started a free trial lesson for us. I was wondering why nobody else happened to be there, but after half an hour some Japanese couples appeared and started practicing on their own. I got to know that they were training for an amateur competition in September and as far as I could see they seemed very absorbed in their step combinations. This confirmed my opinion that even in small circles, it is a logical consequence to aim at a competition when starting dancing and therefore social dance per se is not a means of sociability in Japan.

12 For information see http://www.geocities.jp/dance_kic, accessed February 2009. 


\title{
Social dance and body contact
}

In this section I will discuss social dance in regard to body contact and tactile communication. As I explained earlier, social dance is often called a sport and only mentioned in relation to dance competitions. The reasons are various: on the one hand the connection of social dance to the füzoku eigyōhō, on the other hand the intimate body contact which has no basis in Japanese culture, as the narrator explains at the beginning of the Japanese movie Shall We Dansu?:

\begin{abstract}
In Japan, ballroom dancing is regarded with much suspicion. For a couple to embrace and dance in front of others is beyond embarrassing. A married couple would never think of going out arm in arm, let alone dancing together! A couple would hardly say, 'I love you', out loud. The Japanese rather think that intuitive understanding is everything. To dance with someone other than one's partner would be misunderstood and prove more shameful. Nonetheless, even for Japanese people, there is a secret wonder about the wondrous joys that dancing can bring. ${ }^{13}$ (Suō 1996a)
\end{abstract}

\section{Non-verbal communication and 'skinship'}

Non-verbal communication, communication without talking or writing, includes body movement, gestures, mime and eye contact as well as voice, space, smell, colour symbolism and clothes (Ishii 1987: 3). Every culture has defined the meanings of these components, especially in body contact. Some researchers divided cultures into low-touch cultures (such as Asian or North European) and high-touch cultures (such as Arab and East European) (Ferraro 2002: 91). This hypothesis is quite generalising, because one has to consider that the amount of body contact depends on age, sex and relationships. Taking a look at Japan, Japanese culture is often regarded as a non-touch culture (hisesshoku bunka 非接触文化). To cite some habits of everyday life: greetings are made without handshakes or hugs, instead of touching the other party information is transmitted through bowing (o-jigi お辞儀). After the Meiji Tennō exchanged handshakes with the American President Grant, it became usual to shake hands among politicians or sport teams. But in general, body contact is still avoided in everyday life. One reason might have its origin in the thought of ritual impurity (kegare 穢れ) as transmitted in Shintō or Buddhism. Impurity could infect others through physical contact or even through passing over objects. To maintain one's purity, kegare was avoided in Japan, and even now uncleanness evoked by death, birth and blood can be cited as a taboo (Antoni 2001: 125).

13 Note that this is only the text for the version which was distributed outside Japan by Miramax. For the Japanese audience the introducer and narrator explained the origins of social dance in Europe and America (Suō 1996b: 14). 
The importance of non-verbal communication has often been stressed by Japanese researchers, who distinguish between eight kinds ${ }^{14}$ of body contact: touch (fureru 触れる), clapping (tataku 吒く), grasping (nigiru 握る), folding (kumu 組む), hugging (daku 抱く), carrying on the back (seou 背負う), pulling (hipparu引つ張 る) and pushing (osu 押す) (Kawakita 1995: 12).

In general, body contact is called 'skinship' in Japanese. Skinship is an English word invented in Japan which was first used to describe the body contact through naked skin between mother and child, but is now extended to other relationships as well. According to the Nihongo Daijiten 日本語大辞典 (1989) there are two forms of skinship: body contact in general and a method of childrearing. The mother often touches her baby to make it feel secure and comfortable and this close contact is necessary for the intellectual, emotional and physical development of a child. Body contact with a child expresses parental love and security (Lebra 1976: 140-142).

In Japan, skinship during childhood is very important, but ends when children enter school. Till primary school, families sleep or take a bath together, but when the children grow older such chances for natural body contact decrease. For high school students and later adults, body contact with family members is avoided because both parties feel uncomfortable in showing feelings clearly. Thus non-verbal communication is often reduced in public spaces, because it is for the main part the expression of affection (Barnlund 1975: 35-36). Different to a child, an adult can use language to express feelings and thoughts and does not have to use non-verbal communication. The most common way of showing belongingness to an opposite-sex friend (lover, partner) is holding hands, which has become an accepted form of body contact in public spaces.

Sociologist Dean C. Barnlund conducted a survey about the amount of touching in Japan and America in the 1970s in which he examined the skinship between young people and their mothers, fathers, same-sex friends and opposite-sex friends. According to this comparative study, Japanese young people hardly touched their opposite-sex friends except in such body regions as hands, shoulders and arms. One of my interview partners told me that she 'experienced skinship the first time when she had a boyfriend', another that 'one has to be careful concerning the feeling of distance when going on the street or talking with the opposite sex' (Veemees 2006a: 49-50).

It can be said that body contact is the result of close relationships in Japan (like couples or intimate friends). As it not accepted in public places, body contact is limited to body parts such as hands, shoulders and arms. Apart from handshaking with strangers, these kinds of body contact are mostly seen among close friends. But in many social dances body contact on hips, shoulders and thighs is inevitable. Con-

14 Whereas the American researcher Michael Arguyle distinguished between 16 ways of body contact in European and American societies (Ferraro 2002: 90). 
sidering that a person dances with complete strangers in dance schools, it shows how unusual social dance must be in Japan.

\section{Social dance and skinship}

The term 'personal space' (kyorikan 距離感) has been proposed by Edward Hall and can be divided into four zones: intimate zone up to $50 \mathrm{~cm}$, personal distance $(50 \mathrm{~cm}$ to $1 \mathrm{~m}$ ), social zone (1m to $3 \mathrm{~m}$ ) and public zone (over $3 \mathrm{~m}$ ). When somebody enters another's intimate zone, that person does not feel comfortable. Social dances play with this intimate connection, as we can see in this section.

Social dances can be divided into three groups: Standard dances (slow waltz, quickstep, slow foxtrot, tango, Viennese waltz), Latin-American dances (rumba, samba, paso doble, cha-cha, jive) and party dances (mambo, jitterbug, blues). The Standard and Latin-American dances represent the ten dances which have been united by the Imperial Society of Teachers of Dancing (ISTD) and are known as English style.

Standard dances impress by their fast movements which are made possible by the dance partners' body connection. Two dancers will be one body in balance and spins. Body contact is granted on breast (below the ribs) and groins. The left leg of the woman should be behind the right leg of her partner and the hips should maintain body connection steadily (Krombholz and Haase-Türk 2004: 25-26). Furthemore, the tango (called the most erotic dance) also implies body contact between the thighs of the dance partners.

On the contrary, Latin-American dances concentrate on small space where the dancers remain in some distance to each other. The male dancer places his right hand on the shoulder blade of the woman, body contact is reduced to arms, hands and shoulders (Krombholz and Haase-Türk 2004: 146-147).

As we can see, the difference between Standard and Latin-American dances is the amount of body contact. Looking at traditional Japanese dance, dances with intimate body contact never existed in Japanese culture. In Japanese dance, song or speech play a significant part of the performance. Bon-odori 盆踊り (Bon dances), a circle-dance, or Para Para (disco dance) are popular too, but danced either alone or in groups. Kodera Yūkichi, who did considerable research on this subject, wrote in 1928:

In Japan there never existed a kind of social dance. Even when the aristocrats enjoyed bugaku [舞楽] and the warriors shimai [仕舞い], these dances didn't have the aim of sociability. The way one dances at weddings or parties abroad, is completely different to the situation in Japan. When you take a look at farm villages in Japan, you might feel strange because nobody dances as a couple. (Nagai 1991:239) 
As a matter of fact, among about 692 Japanese participants in an online questionnaire, 42 percent preferred Latin-American dances, 21 percent voted for Standard and 37 percent could not say which of them. Among the best-liked dances the top place was covered by cha-cha, followed by other Latin-American dances. The slow waltz took fifth place (Ryun 2005: StandardLatin). One reason for this result may be the music: modern pop music can be integrated very well into Latin-American rhythms. My hypothesis is that in Latin-American dances body contact is not needed and they are therefore more pleasant to learn. Dance lessons start with easy party dances (mambo, jitterbug) without much body contact, then Latin-American dances are tried and usually difficult Standard dances follow last. The mambo is danced at $50 \mathrm{~cm}$ to $1 \mathrm{~m}$ distance from the partner and even beginners can learn it 'without trouble and anxiety' (Kaneko 2003: 164).

\section{Social dance and communication}

Social dance is a couple's dance traditionally danced between a man and a woman who enable communication without words, just by body movements. Dancers are tied together by a so-called connection which must be maintained throughout the dance. The aim has always been the pleasure of body movements, sexual perception of the partner and courting. Since social dance became a competitive sport, the sexual component in particular can be said to have been lost. Nevertheless the sexual part is one of the points always stressed among Japanese dancers and critics. The attitude towards social dance only changes when one starts dancing oneself.

Ballroom dancer Aramachi Makio was bewildered when seeing a dance lesson for the first time: 'Who is dancing such an indecent (iyarashii 嫌らしい) dance? Man and woman press their bodies together [...] I cannot do this!' (Aramachi 2006: Sanjussai de otozureta tenki)

Those who are open to social dance and start to practice become aware of the reaction in their environment. Many female dancers complain about gossip in internet forums:

When I started dancing, I didn't go out alone with male dancers, because of the rumours. But I'm dancing for a very long time now, have a dance partner and I do not care about other people any more. We go to dance school together and when we are hungry we go out and eat together. It's not unusual anymore, because we touch each other while dancing (Aoba no kai 2000).

Especially dancing with someone other than one's husband or wife is regarded suspiciously:

I live in the countryside and everybody looks at me like I'm a stranger, because I'm doing shakō dansu. If somebody should dance at competitions with someone else than hus- 
band/wife, it would be a scandal. Of course, it might be a characteristic of this region [...] but to deny the fantasies of others is really hard. (Aoba no kai 2000)

I want to take a look at the reasons why such problems occur and how they can be solved.

\section{Social dance is 'hazukashii'}

Often social dance is called hazukashii 恥かしい, a word that is used to express embarrassment. According to the Nihongo Daijiten (1989), there are two meanings: (1) shyness, (2) being ashamed. A distinction can be made between communication anxiety ${ }^{15}$ (like taijin kinchō 対人緊張 [nervousness in front of others] and taijin konwaku 対人困惑 [bewilderment]) and shyness ${ }^{16}$ (like haji 恥 [shame] and tere 照 れ [awkwardness]) (Sugawara 2001a).

Shyness is defined as an emotional reaction on new experiences (Lewis 1993: 112-113). The feeling of being afraid is called $k y o f u$ 恐怖 in Japanese. Many sociologists have attested that Asian cultures are especially shy; it is a fear of the reaction of others to one's appearance and behaviour. This kind of shyness is the main obstacle to entering a dance school. Many passionate dancers started social dance after a recommendation from friends. A dance fan writes on the internet:

I waited long till I advised others to dance too. It is always embarrassing (hazukashii) to sing, talk or dance in front of others. This thought has become a Japanese identity which crosses generations. What did I feel when starting social dance? It is difficult to say. Let's say 'Dance is not so bad'. I'm sure the number of Japanese who think that it is hazukashii to dance will decrease - like karaoke! When you go to a dance school the first time, you will need courage. Everybody is afraid to enter a world one doesn't know. (Byakuya Shobō 2003: Dance Fan Column 2, 4)

Apart from shyness hazukashii also means shameful. Let's have a look at this aspect as it concerns social dance. The Nihon Kokugo Daijiten (2000) says that to be ashamed is 'feeling awkward and helpless after a personal defeat'. The individual is sure to have violated social expectations, values and norms through certain behaviour. Further, the person himself is sensitive about the reactions from outside (haji no kanjuse $i$ 恥の感受性). Especially in child-rearing, Japanese mothers may use the phrase 'seken ni warawareru' 世間に笑われる (everybody will laugh at you) when the child does not behave correctly. To avoid such conflicts the members of a group join together and adapt their behaviour. The individual is therefore afraid to do 
something without the group (Doi 1982: 64-66). Ballroom dancer Aramachi Makio (2006: Sanjussai de otozureta tenki) said:

It would be the best to go to a dancing school. But it would be hazukashii to go there alone and watch... I would be nervous (kiokure 気後れ), because I'm shy (terekusai 照れくさ い). Fortunately somebody among my friends who does social dance came back at that time and I asked him to accompany me.

In every culture indecency causing shame is defined differently. Behaviour is indecent when it disregards the moral standard implied by society. As a reason, social dance which is called 'indecent' in Japan can be a cause for shame. For example, Nishikawa Yoshie, who worked as an assistant for the TV dance show Dansu wa ichiban, explained that 'it was hazukashii to dance with a male dancing teacher' (Miya 2005: 44). My female interview partner Y. M. told me that she learned a kind of folkdance when she was in high school. There the girls had the possibility to dance with a boy and most of the girls (and the boys too) said hazukashii (Veemees 2006a: 67).

To solve such problems folk dances were added to the curriculum of elementary and junior high schools in the 1950s (Nagai 1991: 246). Folk dances are danced in pairs of same sex as well as in pairs of different sex by holding hands, which might be a good preparation for social dance, but may also cause dislike against dance. For this reason, one university dance club propagates the following text:

We don't have the possibility to touch with social dance in everyday life and there are many people who ask themselves what social dance is. Our circle enables you to get to know social dance. Perhaps you will need courage to start. People who don't know about it may resist. But if you are interested, you should take this challenge. It is a real disadvantage to be shy (hazukashigaru). (Shakō Dansu Ichōkai 2000: Shinnyūsei he no messēji)

\section{Possibilities of communication}

Japan is an ageing society, 18.5 percent of the population is older than 65 years. In the 1970s and 1980s, middle-aged people started social dance at newly established community centres (kominkan 公民館). Many of them also run dance circles which give parties and dance lessons at local gymnasiums (Nagai 1991: 249). Social dance is therefore also called toshiyori no supōtsu 年寄りのスポーツ (sport of old people). Of course, there are young people too who do social dancing but they are mostly professional competitive dancers.

Dance is known as being good for the health, for the brain and mind. Body movement and the choreographies of social dance help to prevent dementia and other diseases. Dancers are sociable and new friendships can be built up easily. A 70-year old female dancer told me at an amateur competition where she happened to 
be competing that she had been dancing for 30 years and started because it was healthy. Whereas other sports such as tennis are too heavy and strenuous, social dance is perfect to prevent serious illnesses and should bring something eventful to life in old age.

I have discussed above the thought that social dance is strongly connected with a feeling of shyness and shame. This feeling changes throughout life: for example, the elderly (those retired from work, etc.) do not count as shakaijin 社会人 (members of society) any more. For this reason one does not care so much about what others may think. The feeling of hazukashii diminishes. Sugawara Kensuke conducted a study about shame and old age and discovered that elder people feel much more freedom in situations concerning disgraceful behaviour and the opposite sex (Sugawara 2001b). A 43-year old interview partner said:

If a handsome man would ask me now 'Shall we dance?' I could say 'yes' without resistance. But as a young girl I would have been nervous and not able to answer. But I'm older now, have had many experiences and this inner calmness is much more important than thinking what others might think.

As I mentioned, body contact is especially important in social dance, because skinship enables communication. Communication seems to be far more important to elderly dancers than technical skills. Those who are now enjoying social dance are retired men or women who are relieved from housework and child-rearing. They concentrate on their own hobbies and can experience a second youth. Married couples can build up a new hobby together and while talking about it, become a unit. Usually (married) couples are not able to go out alone when children are born. Thus the most common topics are family, child-rearing and money, hobbies together do not exist. Circle dancer Hirose Yoshifumi said that he hardly talked with his wife except about money and children. But he is glad now that they started social dance together and have a communication base (Hirose 2006: 89).

Some dance critics like Nagai (2004) and Kawakita (1995) called social dance 'sexual communication' for elderly people. Doctors of medicine have proved that sexual desire continues until death and is shown in hugs, holding hands, skinship, and communication between the sexes. Social dance favours these hidden desires and relieves mind and body. Unfortunately Japanese dance magazines like Dance Fan and Dance View do not pick up this subject and mainly concentrate on technique and competition. Only in the corner with contributions from readers one can find letters from older dancers who mention these facts. 


\section{Conclusion}

An online survey with 1,148 Japanese-speaking participants showed the image of social dance: in top place, social dance was described as the best way to spend leisure, but in second place social dance was called a sport (Aoba no kai 1999: Imēji). A different survey about the effects of social dance reveals fun and sociability in top place. Assuming that only people who themselves dance took part in this survey, the difference is clear. As an unknown culture, social dance is called a sport, but for insiders it is a means to achieve the original purpose.

My interview partners, who were completely ignorant about social dance, told me that 'it is a sport like street dance or reggae', 'a dance for aristocrats and the European high society' or 'very difficult to learn'. It is evident that social dance has not yet got into Japanese everyday life. Considering the communicational benefits of social dance is a pity that it is only treated as a sport. Social dance could be helpful at schools in teaching manners, respect and relationship to the opposite sex. Furthermore, when going to parties it is necessary to have some experience in social dance. As some Japanese scholars also pointed out, as an adult, social dance is needed in relations to foreigners or in the international scene (Shinoda 2004: 68). Especially in the age of globalisation such skills are absolutely essential. 


\section{REFERENCES}

Antoni, Klaus. "Shintō.” In Grundriß der Japanologie, eds Klaus Kracht and Markus Rüttermann. Wiesbaden: Harrassowitz Verlag, 2001

Aoba no kai 青葉の会. “Dansu kai ankēto” ダンス会アンケート [Questionnaire on dance]. Aoba no kai, 1999. http://www2s.biglobe.ne.jp/ suisen-a/aoba-commonsense-question-1.html, accessed March 2006

Aoba no kai 青葉の会. “Tsumaranai koto?”つまらないこと? [Something boring?]. Blog Aoba no kai, 2000. http://www.ne.jp/asahi/aoba/suisen/aobanokai-hp/bbs/stresskaisyouaoba-coppy002/63671875.html, accessed March 2006

Aramachi, Makio 荒町真樹夫. "Hajime ni 'Dansu no kikkake wa, kuchibeta to agarishō no kokufuku”” 初めにダンスのきっかけは口下手と上がり症の克服 [First of all: “The motive for starting dancing was my defective speech and nervousness']. Maki Dansu Sukūru [Maki Dance School], 2006. http://www.maki2341.com/aramachi/00.htm, accessed March 2006

Barnlund, Dean C. Public and Private Self in Japan and the United States. Communicative Styles of Two Cultures. Tōkyō: The Simul Press, 1975

Bollinger, Richmod. La donna è mobile. Das modan gāru als Erscheinung der modernen Stadtkultur. Wiesbaden: Harrassowitz, 1994

Brainard, Ingrid. "Gesellschaftstanz. Mittelalter.” In Tanz, ed. Sibylle Dahms. Stuttgart: Bärenreiter-Verlag, 2001

Byakuya Shobo. "Dance Fan Column 1-18”, Dance Fan, 2003. http://www.byakuyashobo.co.jp/dance-fan/column/selectiontop.html, accessed April 2006

CIO (Kakufushō Jōhōka Tōkatsu Sekininsha 各府省情報化統括責任者) Renraku Kaigi 連絡会 議, “Fūzoku eigyōhō” 風俗営業法 [Law concerning entertainment and sex industry]. Hōrei Dēta Teikyō System, 2004. http://law.e-gov.go.jp/cgi-bin/idxsearch.cgi, accessed March 2006

Doi, Takeo. Amae - Freiheit in Geborgenheit. Zur Struktur japanischer Psyche. Frankfurt/Main: Suhrkamp, 1982

Ferraro, Gary P. The Cultural Dimension of International Business. Upper Saddle River NJ: Prentice Hall, 2002

Fukuzawa, Yukichi. Eine autobiographische Lebensschilderung [trans. Gerhard Linzbichler]. Tōkyō: Deutsch-Japanische Gesellschaft, 1971

Goldstein-Gidoni, Ofra, and Michal Daliot-Bul. "Shall We Dansu?: Dancing with the 'West' in contemporary Japan.” Japan Forum 14 (1) (2002): 63-75

Hirose, Yoshifumi 広瀬好文. “Shakō dansu wo hajimeta kikkake wa yappari 'Shall We Dansu'?” 社交ダンスを始めたきっかけはやっぱり「シャル・ウィ・ダンス」 [The reason to start social dance was 'Shall We Dansu?']. Dance Fan 241 (2006): 89

Ishii, Satoshi. Nonverbal Communication in Japan. Orientation Seminars on Japan 28. Tōkyō: The Japan Foundation, 1987

Kaneko, Akira 金子明. Otōsan no shakō dansu お父さんの社交ダンス [Social dance for fathers]. Tōkyō: Modan shuppan, 2003

Kawakita, Nagatoshi 川北長利. Shakō dansu hyōronshū 1932-1995 社交ダンス評論集 19321995 [Essays on social dance 1932-1995]. Suita: Kansai daigaku shakai gakubu, 1995

Kawakita, Nagatoshi 川北長利. Kawakita Nagatoshi Shakō dansu hyōronshū: Kōreishakai ni okeru 'kyōsei' wo mezashite 川北長利社交ダンス評論集:高齢社会における「共生」を目 指して [Essays on social dance: Aiming for “symbiosis" in old age society]. Fujisawa: Shōnan Good, 2002

Krombholz, Gertrude and Haase-Türk, Astrid. Tanzen. Die zehn Standard- und Lateintänze. München, Wien, Zürich: BLV, 2004 
Kuno, Akiko. Unexpected Destination:. The Poignant Story of Japan's First Vassar Graduate. Tōkyō: Kodansha International, 1993

Lebra, Takie Sugiyama. Japanese Patterns of Behavior. Honolulu HI: University Press of Hawaii, 1976

Lewis, Michael. Scham. Annäherung an ein Tabu. Hamburg: Ernst Kabel Verlag, 1993

Linhart, Sepp. “Sakariba: Zone of 'Evaporation' Between Work and Home?” In Interpreting Japanese Society: Anthropological Approaches, eds Joy Hendry and Jonathan Webber. JASO Occasional Paper No. 5. Oxford: JASO, 1986: 198-210

Makino, Susumu 牧野進. Shakō dansu no konseki 社交ダンスの今昔 [Present state and history of social dance]. Tōkyō. Bungeisha, 2003

Mehl, Margaret. "Dancing at the Rokumeikan: A New Role for Women?" In Japanese Women: Emerging from Subservience, 1868-1945, eds Tomida Hiroko and Gordon Daniels. Folkestone, UK: Global Oriental, 2005

Miya, Yoshiko 宮淑子. “Kantō intabyū Nishikawa Yoshie-san: Bangumi shutsuen no fūfu kappuru o mite iru to dansu tte hontō ni ii na, to omoimasu” 巻頭インタビュー西川良江さん : 番組出演の夫婦カップルを見ているとダンスって本当にいいな、と思います [Interview with Nishikawa Yoshie: When I watch spouses dancing in our program, I start thinking 'Dancing is so beautiful'], Dance Fan 239, 2005: 44-46

Miyake, Tsuyako 三宅艶子. “Watashi, modan gāru”私は、モダンガール [I'm a modern girl]. In Nihonjin. Ichiokujin no Shōwashi. Sandai no onnatachi 日本人。一億人の昭和史。三代 の女達 [The Japanese. Shōwa history of 100 million people. Women of three generations], ed. Mainichi Shinbunsha. Tōkyō: Mainichi Shinbunsha, 1981

Nagai, Yoshikazu 永井良和. Shakō dansu to Nihonjin 社交ダンスと日本人 [Social dance and the Japanese]. Tōkyō: Shōbunsha, 1991

Nagai, Yoshikazu 永井良和. “Modan toshi no dansu hōru” モダン都市のダンスホール [Dance halls of modern cities]. In Korekushon. Modan toshi bunka daiyonkan コレクション. モダ ン都市文化第四巻 [4th vol. in collection about modern culture in cities], ed. Wada Hirofumi. Tōkyō: Yumani shobō, 2004

Nakagawa, Saburō 中川三郎. Dansu gannen: Nihon dansu hyakujūsannen zenshi ダンス元年:日 本ダンス百十三年全史 [The first year of social dance: Complete history of 113 years of dance in Japan]. Tōkyō: Gekijō kōba, 1977

Nakashima, Kenzō 中島健蔵. Dokyumento Shōwa Sesōshi Senzenhen ドキュメント昭和世相史 戦前編 [Documents on history of social conditions in Shōwa Japan. Pre-war collection]. Tōkyō: Heibonsha, 1975

Neuss-Kaneko, Margret. Familie und Gesellschaft in Japan. München: C.H. Beck, 1990

Nihongo Daijiten 日本語大辞典. Tōkyō: Kōdansha, 1989

Nihon Kokugo Daijiten 日本国語大辞典. Tōkyō: Shōgakukan, 2000

NTV (Nihon Television Network Corporation). “Geinōjin Shakō Dansu-bu” 芸能人社交ダンス 部 [Performers social dance club] 2006, www.ntv.co.jp/urinari/dance.html, accessed April 2006

Ryun, Ryun. “Shakō/Kyōgi dansu shumoku ankēto”社交・競技ダンス種目アンケート [Questionnaire on social and ballroom dance]. Shakō Dansu Latino - Chachacha, 2005. http://latino.tm.land.to/Standard_Latin/index.php, accessed February 2006

Savigliano, Marta E. "Tango in Japan and the world economy of passion." In Re-made in Japan: Everyday life and consumer taste in changing society, ed. Joseph J. Tobin. New Haven CT, London: Yale University Press, 1992

Segawa, Masahisa 瀬川正久. Jazu de odotte ジャズで踊って [Dancing to Jazz]. Tōkyō: Seiryū shuppan kabushiki geisha, 2005 
Seidensticker, Edward. Low City, High City. Tokyo from Edo to the Earthquake. New York: Alfred A. Knopf, 1983

Shakō Dansu Ichōkai 社交ダンス銀杏会. “Katsudō naiyō shōkai”活動内容紹介 [Information on activities]. Shakō Dansu Ichōkai, 2000. http://www.hh.iij4u.or.jp/ yujiu/ityoukai/main_frame.htm, accessed February 2009

Shall we dansu? Shall we ダンス [Shall we dance?] Directed by Suō Masayuki 周防正行. Daiei 大映 (now Kadokawa Pictures Inc.), 1996

Shinoda, Manabu 篠田学. “Gakkō kyōiku to shakō dansu” 学校教育と社交ダンス [Education and social dance]. Joshi taiiku 46 (2004): 66-68

Sugawara, Kensuke 菅原健介. “Hazukashisa to wa donna kanjō o sasu no ka?”恥かしさとはど んな感情を指すのか [Which feelings express 'hazukashisa'?]. Hazukashii hanashi no kenkyūshitsu 恥かしい話の研究室 [Research on shame], 2001a.

http://www5b.biglobe.ne.jp/ sken/hp/psychology.embarrassment/resarch\%20room/kenkyu.ht m, accessed February 2009

Sugawara, Kensuke 菅原健介. “Kōrei ni naru to hazukashisa wa usureru no darō ka?” 高齢にな ると恥かしさは薄れるのだろうか? [Is the feeling of shame reduced in old age?]. Hazukashii hanashi no kenkyūshitsu 恥かしい話の研究室 [Research on shame], 2001b. http://www5b.biglobe.ne.jp/ sken/hp/psychology.embarrassment/resarch\%20room/kenkyu.ht m, accessed February 2009

Suō, Masayuki. "Shall we dansu?" Shall we ダンス [Shall we dance?], film 1996a

Suō, Masayuki 周防正行. “ “Shall We Dansu?' Kyakuhon”「Shall we ダンス」脚本 [Shall we dance? Screen Play]. Shinario 52(2) (1996b): 13-50

Takahashi, Keiji 高橋桂二. “Shin-shakō dansu to zenkoku butōjō kyōjusho dansā annai” 新社交 ダンスと全国舞踏場 [The new social dance and information on country-wide dance halls, dance schools and dancers] (1933). In Korekushon. Modan toshi bunka daiyonkan [4th vol. of a collection about modern culture in cities], ed. Wada Hirofumi. Tōkyō: Yumani shobō, 2004

Takeuchi, Takao 竹内孝夫. Teikoku Hoteru monogatari 帝国ホテル物語 [Story of Hotel Imperial]. Tōkyō: Gendai Shokan 1997

Tanizaki, Junichirō 谷崎潤一郎. Chijin no ai 痴人の愛 [The fool's love]. Tōkyō: Shinchōsha, 2005 (first published in 1924-25)

Taylor Atkins, E. Blue Nippon. Authenticating Jazz in Japan. Durham, London: Duke University Press, 2001

Veemees, Kristina. "Shall we Dansu? Gesellschaftstanz in Japan.” MA thesis, University of Vienna, 2006a

Veemees, Kristina. “Gesellschaftstanz in Japan.” OAG Notizen (November 2006b): 10-25, 2006b 


\section{GLOSSARY}

\begin{tabular}{|c|c|c|}
\hline ANAD & 全日本ダンス協会連合会 & $\begin{array}{l}\text { Zen Nippon dansu kyōkai rengōkai. } \\
\text { All Nippon Association of Dance, } \\
\text { established in } 1985 . \\
\text { http://www.zendaren.or.jp/ }\end{array}$ \\
\hline beiei kyōrakushugi & 米英享楽主義 & American-British hedonism \\
\hline bon-odori & 盆踊り & $\begin{array}{l}\text { bon dances, which are danced } \\
\text { during summer; can be compared } \\
\text { with circle dances }\end{array}$ \\
\hline bōrurūmu dansu & ボールルームダンス & $\begin{array}{l}\text { ballroom dance; describing social } \\
\text { dances like tango, waltz in the West } \\
\text { and meaning competitive dance } \\
\text { sport in Japan }\end{array}$ \\
\hline bunmei kaika & 文明開化 & $\begin{array}{l}\text { Westernisation movement which } \\
\text { started after the opening of Japan } \\
(\text { kaikoku })\end{array}$ \\
\hline daku & 抱 $<$ & hug \\
\hline dansu sakuru & ダンスサークル & $\begin{array}{l}\text { dance club (mostly for the elderly } \\
\text { people) }\end{array}$ \\
\hline dansu supōtsu & ダンススポーツ & dance sport \\
\hline Dansu wa ichiban & ダンスは一番 & TV dance program \\
\hline Fukuzawa Yukichi & 福沢諭吉 & author, writer, teacher (1835-1901) \\
\hline Fureru & 触れる & touch \\
\hline füzoku eigyōhō & 風俗営業法 & $\begin{array}{l}\text { (called füeihō) law controlling the } \\
\text { Japanese entertainment, restaurant } \\
\text { and sex industry }\end{array}$ \\
\hline geisha & 芸者 & Geisha \\
\hline haji & 恥 & shame \\
\hline haji no kanjusei & 恥の感受性 & sensitivity caused by shame \\
\hline hazukashii & 恥かしい & $\begin{array}{l}\text { (1) shyness (2) being ashamed. The } \\
\text { verb hazukashigaru 恥かしがる } \\
\text { means "to be shy of something" }\end{array}$ \\
\hline hipparu & 引っ張る & pull \\
\hline hisesshoku bunka & 非接触文化 & $\begin{array}{l}\text { non-touch culture; culture with a } \\
\text { very low amount of body contact }\end{array}$ \\
\hline ibunka & 異文化 & foreign culture; unknown culture \\
\hline ISTD & & $\begin{array}{l}\text { Imperial Society of Teachers of } \\
\text { Dancing. Dance teaching and ex- } \\
\text { amination board based in London, } \\
\text { established in } 1904 \text {. }\end{array}$ \\
\hline iyarashii & 嫌らしい & unpleasant, disgusting, indecent \\
\hline JATD & 日本舞踏教師協会 & $\begin{array}{l}\text { Nihon butō kyōshi kyōkai. Japanese } \\
\text { Association of Teachers of Danc- } \\
\text { ing, founded in } 1931 .\end{array}$ \\
\hline
\end{tabular}


JBDF

JDSF

joky $\bar{u}$

Kagetsuen

Kaibara Ekken

kaikoku

Kawakita Nagatoshi

kegare

kiokure

Kōkai nikki

kōminkan

kumu

$k y \bar{f} f u$

kyōgi dansu

kyorikan

Meiji jidai

moga

Muragaki Norimasa

Nagai Yoshikazu

nigiru

Nyonin geijutsu

$o-j i g i$

Ōsaka Mainichi Shim-

bun

osu

otoko wa soto, onna wa

uchi
日本ボールルームダンス連盟Ｎippon bōrurūmu dansu renmei. Japanese Ballroom Dance Federation, established in 1992. http://www.jbdf.or.jp/

Nippon dansu supōtsu renmei. Japanese Dance Sport Federation. Established in 1977 as Japanese Amateur Dance Assocation. http://www.jdsf.or.jp/index-j.html waitress, hostess; new business which emerged during the Taishō period

amusement park in Tsurumi (Yokohama) opened in 1920

Confucian moralist (1630-1740) opening of Japan to the world in 1854

dance critic (1905-2001)

ritual impurity

nervousness, timidity

'Voyage diary' the diary of the first Japanese Embassy to the United States of America; written by Muragaki Norimasa (1813-1880)

community centre

fold

being afraid

competitive dance

personal space, proposed by Edward Hall

Meiji period 1868-1912 modern girl

Vice-ambassador of the Japanese Embassy to the United States of America (1813-1880)

sociologist, Kansai University (b. 1960)

grasp

Womens magazine of the 1920 s and 1930s

bowing

Ōsaka Daily Newspaper, founded in 1876

push

'Men have to work outside, women have to protect the home.' 
RAA

Rokumeikan

sakariba

seken ni warawareru

seou

shakaijin

shakō dansu

shakōsei

shokuba dance

shokugyō fujin

skinship

soshiaru dansu

taijin kinchō

taijin konwaku

Taishō jidai

tataku

teikoku hoteru

tere

terekusai

toshiyori no supōtsu
特殊慰安施設協会

鹿鳴館

盛り場

世間に笑われる

背負う

社会人

社交ダンス

社交性

職場ダンス

職業婦人

スキンシップ

ソシアルダンス

対人緊張

対人困惑

大正時代

吒く

帝国ホテル

照れ

照れくさい

年寄りのスポーツ
Tokushu ian shisetsu kyōkai. Recreation and Amusement Association, which was set up by the Japanese government in 1945 to protect the populace from rape, as the slogan said. In fact, Japanese women (mostly prostitutes) were hired as sex partners for the American army. The RAA was terminated in 1946.

name of the Meiji-era building where balls and banquets were held; opened in 1883, closed in 1887; this period is called Rokumeikan era (rokumeikan jidai) amusement quarters, mainly for men

everybody will laugh at you carry on the back people within society (e.g. working adults), in contrast to people outside society, e.g. children, retired persons

ballroom dances (Standard/ LatinAmerican) sociability workplace dance; became popular in the $1950 \mathrm{~s}$

working woman

first used to describe the body contact between mother and child, but now extended to other relationships as well social dance; dances where sociability and socialising are the primary focuses of the dancing (folk dances etc.); in Meiji Japan used to describe ballroom dances, now used only for a dancing couple (spouses, lovers) nervousness in front of others bewilderment in front of others Taishō period, 1912-1926 clap Imperial hotel in Tōkyō shyness embarrassing sport of old people 
Urinari geinōjin shakō dansu-bu

zeneraru dansu
ウリナリ芸能人社交ダンス部

ゼネラルダンス
Dance program of NTV (2006)

social dance for amateurs with easy step combinations 